\title{
Linkage disequilibrium between the pseudoautosomal PEPB-1 locus and the sex-determining region of chinook salmon
}

\author{
AR Marshall ${ }^{1}$, KL Knudsen ${ }^{2}$ and FW Allendorf ${ }^{2}$ \\ ${ }^{1}$ Washington Department of Fish \& Wildlife, 600 Capitol Way N., Olympia, WA 98501, USA; ${ }^{2}$ Division of Biological Sciences, \\ University of Montana, Missoula, MT 59812, USA
}

\begin{abstract}
Allele frequency differences between sexes and an excess of heterozygotes in males had suggested that the PEPB-1 locus is sex-linked in chinook salmon (Oncorhynchus tshawytscha). We here estimate less than $1 \%$ recombination between $P E P B-1$ and a growth hormone pseudogene known to be in the sex-determining region (SEX) in 374 progeny from eight experimental matings. We present modified maximum likelihood methods for estimating haplotype frequencies from population samples at a sex-linked locus in which functional alleles occur on both the $X$ and $Y$ chromosomes (pseudoautosomal loci). We find nearly complete linkage disequilibrium between $P E P B-1$ and SEX
\end{abstract}

in 20 population samples from the Puget Sound region of Washington and southern British Columbia. However, allele frequencies at $P E P B-1$ were similar in males and females in 35 population samples from the coast of Washington and the Columbia River basin. Pseudoautosomal regions have been described in a broad taxonomic array of vertebrates and invertebrates, and they are likely candidate regions to find genes associated with differences in life history, morphology, or behavior between males and females.

Heredity (2004) 93, 85-97, advance online publication, 26 May 2004; doi:10.1038/sj.hdy.6800483

Keywords: pseudoautosomal; sex-linkage; linkage disequilibrium; sexually antagonistic genes; Oncorhynchus

\section{Introduction}

Muller (1914) proposed that heteromorphic sex chromosomes evolve through suppression of crossing over between a proto- $X$ and proto- $Y$ (or proto- $Z$ and protoW). Crossover suppression is thought to evolve through the action of modifier loci that reduce recombination between the sex-determining region and syntenic loci when there are allelic variants that are favored in one sex but disfavored in the other (Charlesworth and Charlesworth, 1980; Rice, 1996). The Y chromosome will then degenerate without the effects of $X-Y$ recombination due to an accumulation of recessive lethal mutations that are sheltered by their counterparts on the $X$ chromosome (Charlesworth, 1991; Rice, 1996).

Theory and recent empirical evidence have suggested that the genetic decay of the $\mathrm{Y}$ chromosome may occur rapidly (Rice, 1996). The $\mathrm{Y}$ chromosomes of mammals and Drosophila are nearly devoid of functional genes (Rice, 1996). Only recently has a small pseudoautosomal region been described in humans in which functional genes are found on the $X$ and $Y$ chromosomes and recombination occurs between the $X$ and $Y$ chromosomes (Goodfellow et al, 1986). The central role of mammals and Drosophila in genetics has led to the general view that 'most animal Y chromosomes degenerated long ago'

Correspondence: FW Allendorf, Division of Biological Sciences, University of Montana, Missoula, MT 59812, USA.

E-mail: fred.allendorf@mso.umt.edu

Received 29 September 2003; accepted 17 March 2004; published online 26 May 2004
(Charlesworth, 2002). However, a broader taxonomic view suggests that mammals and Drosophila are exceptions and that both sex chromosomes contain many functional genes across a wide variety of animal taxa.

Pseudoautosomal protein coding loci have been described in a wide variety of vertebrates and invertebrates. Morizot et al (1987) found that functional genes for the creatine kinase enzyme locus are present on both the $\mathrm{Z}$ and W chromosomes of Harris' hawk (Parabuteo unicinctus). Wright and Richards (1983) found that two of 12 allozyme loci (Pep-C and Sod-1) that they mapped in the leopard frog (Rana pipiens) are sex-linked and that two functional gene copies of both loci are found in XY males; in addition, the aconitase- 1 locus is pseudoautosomal in the frog R. clamitan (Elinson, 1983). Functional copies of a peptidase locus are present on both the $\mathrm{Z}$ and $\mathrm{W}$ chromosomes in the salamander Pleurodeles waltlii (Dournon et al, 1988). Two allozyme loci (HEX-2 and SSOD-1) in rainbow trout (Oncorhynchus mykiss) have functional alleles on both $\mathrm{X}$ and $\mathrm{Y}$ chromosomes (Allendorf et al, 1994). Recombination occurs over nearly the entire length of the $\mathrm{X}$ and $\mathrm{Y}$ sex chromosomes of medaka (Oryzias latipes; Nanda et al, 2002). Pseudoautosomal enzyme loci also have been described in invertebrates (eg Siegismund and Christensen, 1992; Berlocher, 1993).

The number of pseudoautosomal loci reported in the literature is likely an underestimate due to the inherent difficulty in detecting them. X-linked loci are readily detected in species with a degenerate $Y$ chromosome by the conspicuous absence of heterozygotes in males because of their hemizygosity. Most pseudoautosomal loci have been detected through inheritance studies. 
Pseudoautosomal loci can be detected in population samples only if there is linkage disequilibrium between the locus under investigation and the sex determining locus (SEX). 'Locus' is used here as a unit that cosegregates not necessarily a single functional gene. Differences in allele frequency between the sex chromosomes will result in an excess of heterozygotes in comparison to expected Hardy-Weinberg proportions in the heterogametic sex (Clark, 1988; Allendorf et al, 1994).

All species in the family Salmonidae are descended from a tetraploid event that occurred approximately 25 million years ago (Allendorf and Thorgaard, 1984). Cytological differences indicate that males are the heterogametic sex in this family (Hartley, 1987; Phillips and Ráb, 2001). These observations have been supported by all-female gynogenetically produced progeny and breeding experiments with sex-reversed females (Donaldson and Hunter, 1982). There is little evidence, however, for the degeneration of the $\mathrm{Y}$ chromosome in salmonids. YY individuals produced by sex-reversal are viable (Chevassus et al, 1988; Scheerer et al, 1991). In addition, most salmonid hybrids (Kanda et al, 2002) do not follow Haldane's rule, which states that the heterogametic sex will be the one which is absent, inviable, or infertile in interspecific hybrids (Haldane, 1922; Laurie, 1997).

The Y chromosome of chinook salmon (Oncorhynchus tshawytscha) appears to be more differentiated from the $X$ chromosome than the $\mathrm{Y}$ chromosome of other Oncorhynchus species are from their X counterpart. Devlin et al (1998) described a long repetitive DNA sequence (approximately $2.4 \mathrm{Mb}$ ) that is restricted to the $\mathrm{Y}$ chromosome of chinook salmon; this repeat was not found on the Y chromosome of eight other Oncorhynchus species. Du et al (1993) described a pseudogene (GH-2p) specific to the $\mathrm{Y}$ chromosomes of chinook salmon that is derived from one of two duplicated growth hormone genes (GH-1 and GH-2). Forbes et al (1994) reported that an intron of $G H-2 p$ is found in male, but not in female, coho and chinook salmon. Thus, the $G H-2 p$ locus must be within the sex-determining region of the $\mathrm{Y}$ chromosome in both of these species. GH-2p is also found on the $\mathrm{Y}$ chromosome of chum salmon (O. keta; Kavsan et al, 1994), pink salmon (O. gorbuscha; Spruell et al, 1999), and masu salmon (O. masou; Zhang et al, 2001).

Allozyme genotypic data have been collected for chinook salmon populations for over 20 years (Utter et al, 1989). Genetic polymorphisms at up to 80 allozyme loci have been used for fishery management purposes (Teel et al, 1999), and more recently for delineating population groups for conservation (Marshall et al, 2000). Differences in allele frequencies between males and females at one of these allozyme loci (PEPB-1) in some population samples suggested that this locus is sexlinked in this species.

In this paper, we test for linkage of $P E P B-1$ and the male-specific $G H-2 p$ locus through inheritance studies. We also describe genotypic frequencies at PEPB-1 in 55 populations sampled throughout Washington and British Columbia. We provide maximum likelihood equations for estimating allele frequencies of a sex linked locus on the $\mathrm{X}$ and $\mathrm{Y}$ chromosomes, and consider the pattern of geographic distribution of $P E P B-1$ alleles on sex chromosomes in light of the genetic population structure of chinook salmon as determined by other allozyme loci and other biological traits.

\section{Materials and methods}

\section{Samples}

Samples of adult wild and hatchery chinook salmon were collected from 55 populations in Washington, Oregon and British Columbia on the spawning grounds or in the hatchery (Figure 1). Samples are lettered-coded in Figure 1 according to population groupings based on genetic, biological, and ecoregional characteristics (Myers et al, 1998). For example, all C populations inhabit Puget Sound rivers, and have similar juvenile life histories, ocean migration routes, and allozyme allele frequencies. Two distinct population groups ( $F$ and $G$, respectively) are sympatric in interior Columbia River basin drainages, and have life-history patterns that correspond to Healey's (1991) 'ocean- and stream-types'. Two different life history phenotypes were collected from the Kalama and Lewis Hatcheries (E group; appendix); the A samples returned to freshwater in the spring and the B samples returned in the fall. Tissues were dissected from adults in the field and transported on dry ice to the laboratory where they were stored at $-80^{\circ} \mathrm{C}$ prior to electrophoresis.

Chinook salmon become sexually mature at from 2 to 6 years of age so that the fish collected in 1 year contained fish of multiple brood years. Some populations were sampled in multiple years. Thus, in some of the samples, we had many males and females from multiple brood years so that we could test for temporal stability of genotypic frequencies. Age was determined by scale pattern analysis (Koo, 1967).

\section{Experimental matings}

Sexually mature fish from the Green River Hatchery (sample C10) and the Cowlitz River Hatchery (E1) were used in the matings. Adults were chosen at random for pair matings, and each family was reared separately. Subyearling juveniles were sampled from each family, analyzed at many allozyme loci, and tested for conformance to expected genotypic ratios based on the parental cross. This was carried out by personnel of the Washington Department of Fish and Wildlife (WDFW), with the primary goal of verifying Mendelian inheritance (JB Shaklee, WDFW, personal communication). We used samples from these matings that had been stored at $-80^{\circ} \mathrm{C}$ for analysis of $P E P B-1$ and SEX.

\section{Protein electrophoresis}

Protein electrophoresis and staining followed methods of Aebersold et al (1987). We used a tris-glycine buffer $(\mathrm{pH}$ 8.5) to separate the ${ }^{*} a$ and ${ }^{*} b$ alleles, and a tris-citrate buffer (pH 5.95) to separate the ${ }^{*} a$ and ${ }^{*} c$ alleles at PEPB-1 (EC 3.4.11.4; Marshall et al, 2000). The protein produced by the most common allele $\left({ }^{*} a\right)$ has a relative electrophoretic mobility of 100 ; the ${ }^{*} b$ and ${ }^{*} c$ proteins have relative mobilities of 130 and -350 , respectively. Muscle and eye tissues were analyzed separately to obtain two independent determinations of PEPB-1 phenotypes; if discrepancies occurred, we ran the samples again to determine the correct phenotype. Allele and locus 


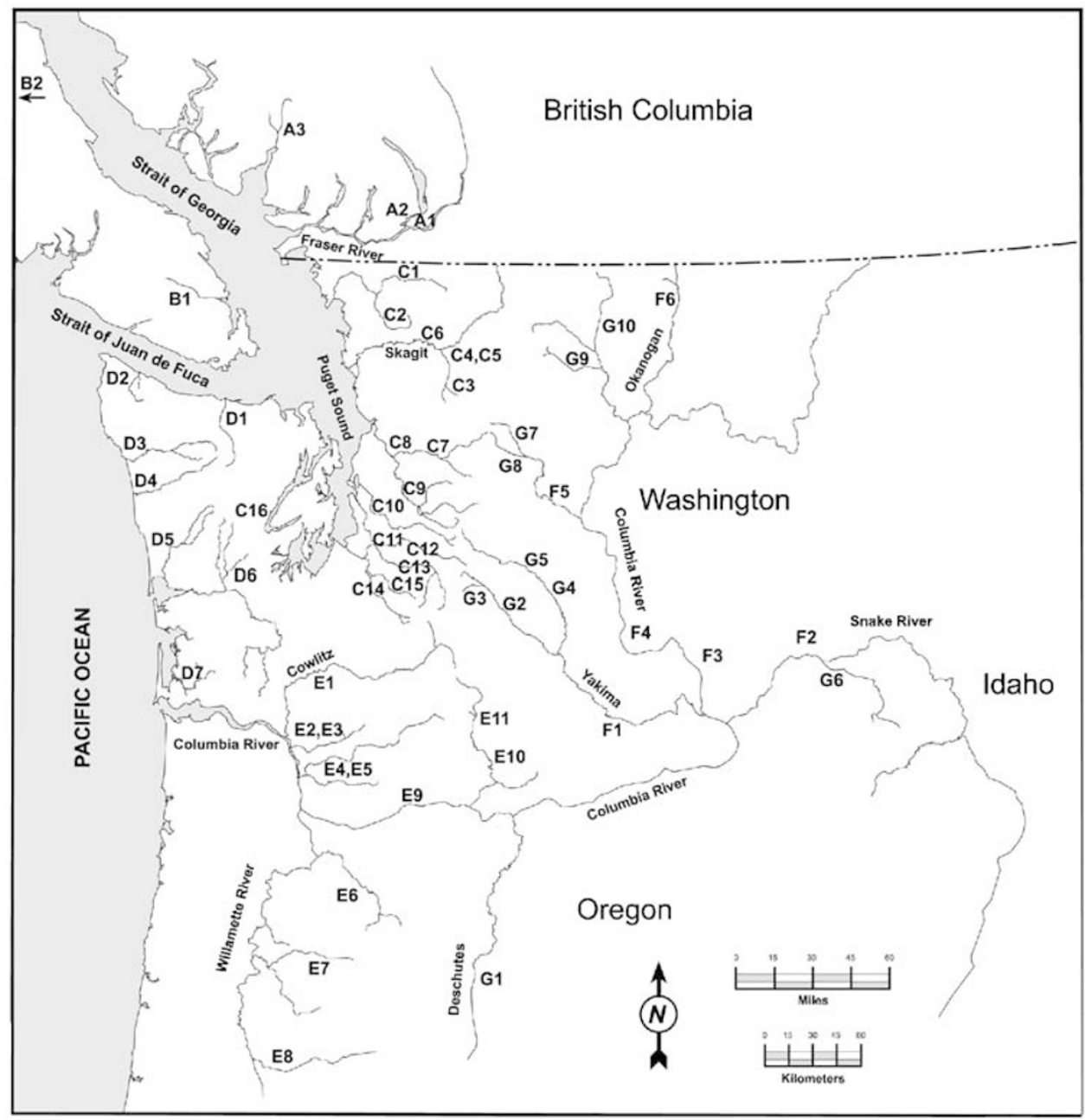

Figure 1 Map of sample locations. Samples codes are given in the appendix.

nomenclature follow American Fisheries Society standards (Shaklee et al, 1990).

\section{Determination of sex}

Sex of adults was determined by visual examination of sexually mature fish. Sex of juveniles in the families used in segregation analysis was determined by testing for the presence or absence of a Y-linked growth hormone pseudogene (GH-2p; Forbes et al, 1994; Du et al, 1993). Primers were those reported by Forbes et al (1994) to amplify intron $\mathrm{C}$ of $G H-2$. DNA from males yields two products: the $\mathrm{GH}-2$ intron $\mathrm{C}(488 \mathrm{bp})$ and the Y-linked pseudogene intron C (456bp); DNA from females produces only the GH-2 intron (Forbes et al, 1994).

DNA was isolated from muscle or liver tissue using the Puregene kit (Gentra System, Minneapolis, MN, USA). PCR mixtures contained 100-200 ng DNA, $10 \mathrm{mM}$ Tris- $\mathrm{HCl}$ (pH 8.3), $50 \mathrm{mM} \mathrm{KCl}, 2.5 \mathrm{mM} \mathrm{MgCl}$, dNTP mix (each at $0.2 \mathrm{mM}$ ), each primer at $0.5 \mu \mathrm{M}$, and $0.5 \mathrm{U}$ Taq DNA polymerase in a total volume of $15 \mu \mathrm{L}$. The temperature profile for amplification was $95^{\circ} \mathrm{C}$ for $1 \mathrm{~min}$ followed by 31 cycles of $92^{\circ} \mathrm{C}(1 \mathrm{~min}), 63^{\circ} \mathrm{C}$ $(1 \mathrm{~min}), 72^{\circ} \mathrm{C}$ ( $\left.2 \mathrm{~min}\right)$. Products were restricted with HinfI, run out on a $2.5 \%$ agarose gel, and visualized by staining with ethidium bromide.

\section{Results}

Inheritance

We tested for sex linkage of $P E P B-1$ by joint segregation analysis of $P E P B-1$ and $G H-2 p$ in progeny from eight heterozygous males mated with females homozygous at $P E P B-1$. We found no recombination between $P E P B-1$ and $S E X$ in seven families from both hatchery populations in which the father was heterozygous ${ }^{*} a b$ (Table 1 ). There were two recombinants in one family from the Cowlitz Hatchery in which the father was heterozygous ${ }^{*} a c$ (Table 1). Pooling over all families, there were two recombinants out of 374 progeny $(r=0.005)$.

\section{Genotypic distributions in populations}

There are dramatic differences between males and females in the genotypic distribution of $P E P B-1$ in many of the 55 populations examined (appendix). For example, 52 of 61 females from the Harrison River (A1) were ${ }^{*} a / a$ homozygotes, while none of the 39 males had this genotype. In total, there were highly significant allele frequency differences $(P<0.001)$ between sexes in 21 of 55 population samples. There is a strong tendency for an excess of heterozygotes in males from those samples in 
Table 1 Joint segregation of PEPB-1 and SEX

\begin{tabular}{|c|c|c|c|c|c|c|c|c|}
\hline \multirow[t]{2}{*}{ Family } & \multicolumn{2}{|c|}{ Parental genotypes } & & \multicolumn{4}{|c|}{ Progeny genotypes } & \multirow[t]{2}{*}{$\mathrm{r}^{\mathrm{a}}$} \\
\hline & Female & Male & & $a a$ & $a b$ & $b b$ & $a c$ & \\
\hline \multirow{2}{*}{ GR704 } & $a a$ & $a b$ & Male & 0 & 27 & 0 & 0 & $0.000^{* * *}$ \\
\hline & & & Female & 23 & 0 & 0 & 0 & \\
\hline \multirow[t]{2}{*}{ GR725 } & $a a$ & $a b$ & Male & 0 & 27 & 0 & 0 & $0.000^{* * *}$ \\
\hline & & & Female & 18 & 0 & 0 & 0 & \\
\hline \multirow[t]{2}{*}{ GR727 } & $a a$ & $a b$ & Male & 0 & 19 & 0 & 0 & $0.000^{* * *}$ \\
\hline & & & Female & 26 & 0 & 0 & 0 & \\
\hline \multirow[t]{2}{*}{ GR728 } & $a a$ & $a b$ & Male & 0 & 23 & 0 & 0 & $0.000^{* * *}$ \\
\hline & & & Female & 23 & 0 & 0 & 0 & \\
\hline \multirow[t]{2}{*}{ GR734 } & $a a$ & $a b$ & Male & 0 & 21 & 0 & 0 & $0.000^{* * *}$ \\
\hline & & & Female & 28 & 0 & 0 & 0 & \\
\hline \multirow[t]{2}{*}{ GR745 } & $b b$ & $a b$ & Male & 0 & 0 & 23 & 0 & $0.000^{* * *}$ \\
\hline & & & Female & 0 & 27 & 0 & 0 & \\
\hline \multirow[t]{2}{*}{$\mathrm{CO} 29$} & $a a$ & $a b$ & Male & 0 & 19 & 0 & 0 & $0.000^{* * *}$ \\
\hline & & & Female & 25 & 0 & 0 & 0 & \\
\hline \multirow[t]{2}{*}{$\mathrm{CO} 44$} & $a a$ & $a c$ & Male & 17 & 0 & 0 & 1 & $0.043^{* * *}$ \\
\hline & & & Female & 1 & 0 & 0 & 26 & \\
\hline
\end{tabular}

${ }^{\mathrm{a}}$ Estimated rate of recombination.

$* * * P<0.001$

The first six families were from the Green River Hatchery (C10) and the remaining two from the Cowlitz Hatchery (E1).

which females and males had different allele frequencies at $P E P B-1$. Both of these results are expected if $P E P B-1$ is sex-linked and there are differences in allele frequencies on the $X$ and $Y$ chromosomes.

In contrast, there is no evidence for allele frequency differences between the $X$ chromosomes in females and the $X$ chromosomes in males. This is supported by two independent observations (Allendorf et al, 1994). First, there is no tendency for an excess of heterozygotes in females as would be expected if allele frequencies differed on the $X$ chromosome from males and females (appendix). In addition, analysis of allele frequencies in females from different age cohorts in many of these populations show no evidence of the changes in allele frequencies that are expected if the allele frequencies on the $X$ chromosomes in females and males differ (data not shown).

\section{Estimation of haplotype frequencies}

The presence of functional alleles on both sex chromosomes makes it difficult to estimate allele frequencies because it is not possible to know on which chromosomes the alleles are carried by a heterozygote of the heterogametic sex. Siegismund and Christensen (1992) have considered the analogous case of $\mathrm{Z}$ and $\mathrm{W}$ chromosomes in which females are heterogametic. Here we consider the expected distribution of genotypes and estimation of haplotype frequencies at a sex-linked locus in which functional alleles occur on both the $X$ and $Y$ chromosomes.

The frequency of allele $i$ on the $X$ chromosomes of females, $X$ chromosomes of males, and $Y$ chromosome is $x f_{i} x m_{i}$, and $y_{i}$, respectively. The genotypic distribution of females the next generation in a random mating population is

$$
\begin{aligned}
& F_{i i}=x f_{i} x m_{i} \text { (homozygotes) } \\
& F_{i j}=x f_{i} x m_{j}+x f_{j} x m_{i} \text { (heterozygotes) }
\end{aligned}
$$

Allele frequency differences between the $X$ chromosomes in females and males will produce an excess of heterozygotes in females relative to binomial (ie Hardy-Weinberg) proportions. The difference between the sexes in the allele frequency on the $X$ chromosome will be halved each generation, regardless of the rate of recombination between the locus being considered and the sex determining locus (Allendorf et al, 1994). At equilibrium $x f_{i}=x m_{i}=x_{i}$, and the genotypic distribution in females will be in binomial proportions so that

$$
\begin{aligned}
& F_{i i}=x_{i}^{2} \text { (homozygotes) } \\
& F_{i j}=2 x_{i} x_{j} \text { (heterozygotes) }
\end{aligned}
$$

In males, the expected genotypic distribution with random mating is given by

$$
\begin{aligned}
& M_{i i}=x f_{i} y_{i} \text { (homozygotes) } \\
& M_{i j}=x f_{i} y_{j}+x f_{j} y_{i} \text { (heterozygotes) }
\end{aligned}
$$

Allele frequency differences between the $X$ chromosomes in females and $Y$ chromosomes will produce an excess of heterozygotes in males. This difference in allele frequency will decrease as a function of the rate of recombination $(r)$ between the locus under consideration and the sex-determining locus so that the expected allele frequency on the $\mathrm{Y}$ chromosome next generation $\left(y^{\prime}\right)$ is

$$
y_{i}^{\prime}=(1-r) y_{i}+r x_{i}
$$


Thus, allele frequency differences between the $X$ and $Y$ chromosomes are expected to persist for long periods of time in the case of tight linkage.

It is difficult to estimate all the haplotype frequencies for a sex-linked locus $\left(x f_{i}, x m_{i}\right.$, and $\left.y_{i}\right)$. Allele frequencies on the $X$ chromosomes in females can be estimated directly from the genotypic distribution in females. However, it is not possible to distinguish maternal (X) and paternal $(\mathrm{Y})$ alleles in heterozygous males. Estimation is simplified when the allele frequencies on the $X$ chromosomes in females and males is assumed equal $\left(x f_{i}=x m_{i}=x_{i}\right)$. This is a reasonable assumption in many cases because the rate of approach to equilibrium of allele frequencies on the $X$ chromosomes in females and males is fast (50\% per generation; Allendorf et al, 1994). We have assumed equal allele frequencies on the $X$ chromosomes in females and males for $P E P B-1$ for the reasons discussed at the end of the previous section.

We calculated the maximum likelihood estimates of allele frequencies (appendix) using the EM algorithm (Dempster et al, 1977) following the approach of Siegismund and Christensen (1992). Let Fij and Mij be the observed number of genotype $i j$ in females and males, $F$ and $M$ be the total number of females and males, and $F i j=F j i$ and $M i j=M j i$. The estimates of the allele frequencies on the $\mathrm{X}$ and $\mathrm{Y}$ chromosomes can be found by iterating the following equations

$$
\left\langle x_{i}\right\rangle=\frac{\left(\sum_{j=1}^{n} F_{i j}+F_{i i}+\sum_{j=1}^{n} M_{i j} \frac{x_{i} y_{j}}{x_{i} y_{j}+x_{j} y_{i}}+\frac{M_{i j}}{2}\right)}{(2 F+M)}
$$

and

$$
\left\langle y_{i}\right\rangle=\frac{\left(\sum_{j=1}^{n} M_{i j} \frac{x_{j} y_{i}}{x_{j} y_{i}+x_{i} y_{j}}+\frac{M_{i j}}{2}\right)}{M}
$$

until allele frequencies converge. We used the observed allele frequencies in females and males for each population sample as starting points for the iterations.

There are large differences in haplotype frequencies on the $X$ and $Y$ chromosomes in some population samples (appendix; Figure 2). For example, the ${ }^{*} a$ allele was at an

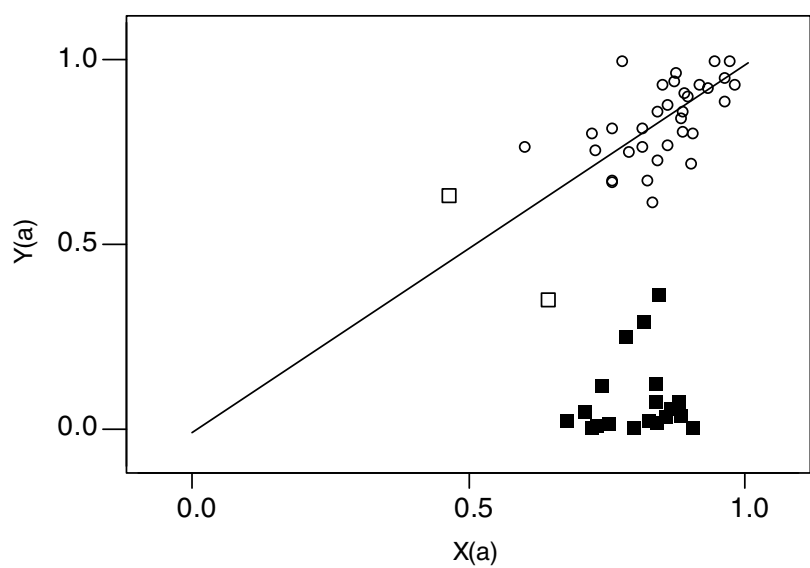

Figure 2 Plot of the frequency of the ${ }^{*} a$ allele on the $X$ and $Y$ chromosomes in 55 samples of chinook salmon. The open boxes and filled boxes indicate samples in which the allele frequencies in females and males are significantly different $(P<0.01$ and 0.001 , respectively). estimated frequency of 0.907 on the $X$ chromosome in the Harrison River sample, but it does not occur on the $Y$ chromosome in this sample. The ${ }^{*} a$ allele was more common on the $X$ than the $Y$ chromosomes in 23 of the 24 population samples in which there are significant allele frequency differences between females and males for this allele (appendix).

In contrast, we found no evidence of divergence in allele frequencies between the $X$ and $Y$ chromosomes in 31 of 55 population samples (appendix). There was no tendency for the ${ }^{*} a$ allele to be more common on the $X$ than the $\mathrm{Y}$ chromosome in these 31 population samples. The frequency of ${ }^{*} a$ was greater on the $X$ than the $Y$ chromosome in 16 population samples and less on the $X$ than the $\mathrm{Y}$ in 15 population samples.

\section{Discussion}

Our inheritance experiments and examination of genotypic distributions in populations confirm that $P E P B-1$ is sex-linked in chinook salmon. The extreme allele frequency differences between males and females at this locus in some populations are maintained by tight linkage between $P E P B-1$ and the sex-determining region. We found only two out of 374 progeny to be recombinants between $P E P B-1$ and $G H-2 p$. Both of these recombinants were in the only family in which the male was heterozygous ${ }^{*} a c$ rather than ${ }^{*} a b$. This suggests the possibility that there is more recombination between the ${ }^{*} a \mathrm{X}$ chromosome and the $\mathrm{X}$ chromosome marked with the ${ }^{*} c$ allele than the ${ }^{*} b$ allele.

We expect different patterns of variation of allele frequencies of loci on the $X$ and $Y$ chromosomes because of differences in effective population size $\left(N_{\mathrm{e}}\right)$. If there is no recombination between a locus and the sex-determining region, then for an ideal population the $N_{\mathrm{e}}$ for a locus on the $X$ chromosome would be $3 / 4$ that of an autosomal locus, and the $N_{\mathrm{e}}$ for the $\mathrm{Y}$ chromosome would be $1 / 4$ that of an autosomal locus (Caballero, 1995). The current situation approaches this expectation because of the low rate of recombination. Thus, we expect a greater proportion of gene diversity on the $\mathrm{Y}$ chromosome to be between populations (Wang, 1999). That is, we expect a greater fixation index $\left(F_{\mathrm{ST}}\right)$ for the $\mathrm{Y}$ than the $\mathrm{X}$ chromosome haplotype frequencies. The overall values of $F_{\mathrm{ST}}$ for the allele frequencies on the $\mathrm{Y}$ chromosome in our samples is 0.592 , in contrast to 0.074 for the $X$ chromosome. The $F_{\mathrm{ST}}$ at 25 autosomal allozyme loci over approximately the same geographical range of populations was 0.123 (Utter et al, 1989).

\section{Linkage disequilibrium}

There is a strong biogeographical pattern to the linkage disequilibrium between PEPB-1 and SEX. Population samples from the Puget Sound region show strong linkage disequilibrium while little linkage disequilibrium is present in coastal and Columbia River populations. The $\mathrm{X}-{ }^{*} b$ haplotype occurs at a low frequency in all three samples (A) from the Strait of Georgia and all 16 population samples (C) from Puget Sound; in contrast, the $Y-b^{*}$ haplotype occurs at a high frequency in these populations. The $X^{*} a$ haplotype occurs at an average frequency of 0.794 in these populations, while the $X^{-*} b$ haplotype occurs at an average frequency of 0.074 . The sample from the Elwha River (D1) has PEPB-1 allele 
frequencies similar to Puget Sound populations, and is distinct from other Pacific coast populations (D). However, this population is more similar to other Washington coast populations at other allozyme loci (Utter et al, 1989).

Significant differences in frequencies of the ${ }^{*} a$ or ${ }^{*} b$ alleles between males and females occur in only three other population samples outside of the coastal and Puget sound population groups (A, C, and D). The ${ }^{*} a$ allele is slightly more frequent in females than in males in two samples from the Columbia River basin (E8 and G3). The ${ }^{*} a$ allele is significantly less frequent in females than males in only one sample, which is from the southern tip of Vancouver Island (B1). The ${ }^{*} \mathrm{c}$ allele is found at significantly different frequencies in males and females from five samples from a wide geographic range (C1, E1, F4, G3, and G9). In three of these samples this allele is more frequent in females, and the reverse is true in the other two samples. This difference is only great in the sample from the Twisp River (G9).

Any differences in allele frequencies on the $X$ and $Y$ chromosomes are expected to persist for a very long time because of the low recombination rate (Clark, 1988; Allendorf et al, 1994). For example, if we start out with alternate fixation of two alleles in males and females, it is expected to take 285 generations before the allele frequencies on the $\mathrm{X}$ and $\mathrm{Y}$ chromosomes are less than 0.10 different in allele frequencies (Allendorf et al, 1994). This same process is expected to take 628 generations until the difference is less than 0.01 . The generation interval of chinook salmon is roughly 4 years (Healey, 1991).

Therefore, the large differences in haplotype frequencies between the $X$ and $Y$ chromosomes in the Puget Sound and Strait of Georgia regions is not surprising in view of the tight linkage between $P E P B-1$ and the sexdetermining region. This linkage disequilibrium suggests the possibility of either a selective sweep that has increased the frequency of the $\mathrm{Y}$ chromosome with the $b^{*}$ allele in this region or a genetic bottleneck associated with the founding of chinook salmon populations in this region. The Puget Sound region and most of British Columbia were ice-covered and much of the Columbia Basin and more southerly Pacific coast areas were not during the last period of glaciation (Thorson, 1980). Colonization of proto-Puget Sound by chinook salmon following glaciation could have caused a genetic bottleneck.

It is perhaps more difficult to understand the lack of divergence in allele frequencies on the $X$ and $Y$ chromosomes in the population samples from the Pacific coast and the Columbia River basin in view of the large divergence in Puget Sound samples. We had suspected that perhaps there was a chromosomal polymorphism resulting in different amounts of recombination between $P E P B-1$ and SEX in the two regions. We tested this by examining inheritance in one hatchery from the region in which there was strong differentiation (Green River, C10) and one hatchery from the other region (Cowlitz River, E1). However, we found tight linkage in crosses from both hatchery populations (Table 1).

Spontaneous sex reversed individuals have been described in many fish species (Francis, 1992). Nagler et al (2001) have reported that in some populations from the Columbia River basin a high proportion of pheno- typically female chinook salmon had male-specific genetic markers. Sex reversal could provide an opportunity for increased recombination between $P E P B-1$ and $S E X$. Recombination rates in rainbow trout are approximately 10 times greater in females than in males for loci in regions proximal to the centromere (Sakamoto et al, 2000). The sex-determining region is near the centromere in rainbow trout (Allendorf et al, 1994; Woram et al, 2003). Thus, it is possible for there to be considerable effective recombination between $P E P B-1$ and SEX in populations that have a high frequency of sex reversed $(X Y)$ females.

\section{Sex chromosome evolution}

Rice (1996) has presented an evolutionary pathway for the accumulation of mutational changes of sex chromosomes that results in eventual degeneration of the chromosome that carries the dominant gender-determining allele (either the $\mathrm{Y}$ or $\mathrm{Z}$ chromosome). The first step is the presence of a single locus that is associated with genic sex determination. A nonrecombining segment then arises surrounding this locus giving rise to semichromosomal sex determination. The nonrecombining region expands and eventually leads to chromosomal determination in which sex chromosomes are heteromorphic, or, in some cases, the eventual loss of the nonrecombining chromosome ( $\mathrm{XO}$ sex determination).

Reduced recombination between $X$ and $Y$ chromosomes may be selected even in the absence of multiple sex determining loci in the case of sexually antagonistic genes in which alleles that are favored in one sex are disfavored in the other. The classic example of this is the guppy (Poecilia reticulata) in which male-benefit sexually antagonistic alleles producing ornamental characteristics are favored in males through sexual selection but are disfavored in females because ornamental characteristics make fish more conspicuous to predators. Winge (1927) found that 17 of 18 major genes producing ornamental characteristics mapped to the sex chromosomes.

Sexually antagonistic alleles at loci unlinked to the sexdetermining region will only increase in frequency if the advantage to one sex is greater than the disadvantage to the other (Rice, 1996). However, this requirement is relaxed at loci that are syntenic with the sex-determining region because such alleles may be preferentially transmitted to sons because of linkage. Suppressed recombination between such loci and the sex-determining region will reduce the production of females with the disfavored phenotype, and thus will be favored by natural selection.

\section{Salmonid sex chromosomes}

There are many life history differences between the sexes in salmon that are candidates for sexually antagonistic effects (Groot and Margolis, 1991). For example, males tend to become sexually mature at earlier ages in many salmonid species. Heath et al (2002) have recently shown that alleles associated with early sexually maturity are present on the $\mathrm{Y}$ chromosome of chinook salmon. They found significantly greater narrow-sense heritability for early sexual maturity from sires $(0.62 \pm 0.21)$ than from dams $(-0.14 \pm 0.12)$. In addition, they used testosterone to 'masculinize' chinook salmon larvae, and found that the $X Y$ males had a much higher proportion of precocious sexual maturity than XX males (31 versus $10 \%$ ). 
The results of Heath et al (2002) suggest the presence of genetic variation for age of sexual maturity on the $Y$ chromosome of chinook salmon. We tested for this in our samples by comparing PEPB-1 allele frequency differences on the $Y$ chromosome of males that matured at age 3 or 4 years within brood years. We found no evidence of allele frequency differences (data not shown). However, the power to detect such differences is not great because our sample sizes were small after collections were divided by both brood year and sex.

Pseudoautosomal regions are a potentially fertile region of the genome to search for loci associated with life history differences between the sexes. Most studies that have identified the genetic basis of male reproductive strategies in fishes have found evidence for sexlinkage (reviewed in Heath et al, 2002). In addition, Goudie et al (1995) found that a pseudoautosomal allozyme locus (GPI-B) in channel catfish (Ictalurus punctatus) was associated with differences in growth rate. The demonstration of pseudoautosomal loci requires inheritance studies. Nevertheless, the tendency for heterozygote excess in the heterogamatic sex in population samples is suggestive of a pseudoautosomal locus. Therefore, population genetic surveys of microsatellite and other types of loci in species that might have large pseudoautosomal regions (eg amphibians or fish) should test for this effect.

\section{Acknowledgements}

We thank S Berlocher and P Hedrick for advice about estimating haplotype frequencies at a pseudoautosomal locus, B Liermann for technical assistance, D Pruitt and S Snyder for making the map, and A Whiteley for his comments. This research was supported by the National Science Foundation (DEB-9300135). J Shaklee identified differences in female and male PEBP-1 allele frequencies and a tendency for heterozygous excess; we are indebted to his assistance with our use of the WDFW inheritance study samples. S Young and his WDFW staff sampled most of the populations. We appreciate the expert work of many WDFW Genetics Lab technicians on allozyme data collection. J Sneva aged all samples. C Busack assisted with population data analyses. We thank B Riddell for allowing us to use the data from British Columbia populations.

\section{References}

Aebersold PB, Winans GA, Teel DJ, Milner GB, Utter FM (1987). Manual for starch gel electrophoresis: a method for the detection of genetic variation NOAA Technical Report NMFS 61, US Dept. Comm., National Oceanic and Atmospheric Administration, National Marine Fisheries Service, Seattle, Washington.

Allendorf FW, Gellman WA, Thorgaard GH (1994). Sex-linkage of two enzyme loci in Oncorhynchus mykiss (rainbow trout). Heredity 72: 498-507.

Allendorf FW, Thorgaard GH (1984). Polyploidy and the evolution of salmonid fishes. In: Turner BJ (ed) Evolutionary Genetics of Fishes. Plenum Press: New York, pp 1-53.

Berlocher SH (1993). Gametic disequilibrium between allozyme loci and sex chromosomes in the genus Rhagoletis. J Hered 84: 431-437.

Caballero A (1995). On the effective size of populations with separate sexes, with particular reference to sex-linked genes. Genetics 139: 1007-1011.
Charlesworth B (1991). The evolution of sex chromosomes. Science 251: 1030-1033.

Charlesworth D (2002). Plant sex determination and sex chromosomes. Heredity 88: 94-101.

Charlesworth D, Charlesworth B (1980). Sex differences in fitness and selection for centric fusions between sex chromosomes and autosomes. Genet Res 35: 205-214.

Chevassus BA, Devaux A, Chourrout D, Jalabert B (1988). Production of YY rainbow trout males by self-fertilization of induced hermaphrodites. J Hered 79: 89-92.

Clark AG (1988). The evolution of the Y chromosome with X-Y recombination. Genetics 119: 711-720.

Dempster AP, Laird NM, Rubin DB (1977). Maximum likelihood estimation from incomplete data via the EM algorithm. J Roy Stat Soc B 39: 1-38.

Devlin RH, Stone GW, Smailus DE (1998). Extensive directtandem organization of a long repeat DNA sequence on the $Y$ chromosome of chinook salmon (Oncorhynchus tshawytscha). J Mol Evol 46: 277-287.

Donaldson EM, Hunter GA (1982). Sex control in fish with particular reference to salmonids. Can J Fish Aquat Sci 39: 99-110.

Dournon C, Collenot A, Lauthier M (1988). Sex-linked peptidase-1 patterns in Pleurodeles waltlii Michah (Urodele Amphibian): genetic evidence for a new codominant allele on the $\mathrm{W}$ sex chromosomes and identification of $\mathrm{ZZ}, \mathrm{ZW}$, and WW sexual genotypes. Reprod Nutr Dev 28: 979-987.

Du SJ, Devlin RH, Hew CL (1993). Genomic structure of growth hormone genes in chinook salmon (Oncorhynchus tshawytscha) - presence of two functional genes, GH-I and GHII, and a male-specific pseudogene, GH- $\Psi$. DNA Cell Biol 12 739-751.

Elinson RP (1983). Inheritance and expression of a sex-linked enzyme locus in the frog, Rana clamitans. Biochem Genet 21: 435-442.

Forbes SH, Knudsen KL, North TW, Allendorf FW (1994). One of two growth hormone genes in coho salmon is sex-linked. Proc Natl Acad Sci USA 91: 1628-1631.

Francis RC (1992). Sexual lability in teleosts - developmental factors. Quart Rev Biol 67: 1-18.

Goodfellow PJ, Darling SM, Thomas NS, Goodfellow PN (1986). A pseudoautosomal gene in man. Science 234: 740-743.

Goudie CA, Liu QH, Simco BA, Davis KB (1995). Genetic relationship of growth, sex and glucosephosphate isomeraseB phenotypes in channel catfish (Ictalurus punctatus). Aquaculture 138: 119-124.

Groot C, Margolis L (1991). Pacific Salmon Life Histories. UBC Press: Vancouver, Canada.

Haldane JBS (1922). Sex ratio and the unisexual sterility of hybrid animals. J Genet 12: 101-109.

Hartley SE (1987). The chromosomes of salmonid fishes. Biol Rev Camb Philos Soc 62: 197-214.

Healey MC (1991). Life history of chinook salmon (Oncorhynchus tshawytscha). In: Groot C, Margolis L (eds) Pacific Salmon Life Histories. UBC Press: Vancouver, Canada, pp 311-393.

Heath DD, Rankin L, Bryden CA, Heath JW, Shrimpton JH (2002). Heritability and Y-chromosome influence in the jack male life history of chinook salmon (Oncorhynchus tshawytscha). Heredity 89: 311-317.

Kanda N, Leary RF, Allendorf FW (2002). Evidence of introgressive hybridization between bull trout and brook trout. Trans Am Fish Soc 131: 772-782.

Kavsan VM, Koval AP, Palamarchuk AJ (1994). A growth hormone pseudogene in the salmon genome. Gene 141: 301-302.

Koo TSY (1967). Objective studies of the scales of Columbia River chinook salmon, Oncorhynchus tshawytscha (Walbaum). Fish Bull 66: 165-180.

Laurie CC (1997). The weaker sex is heterogametic: 75 years of Haldane's rule. Genetics 147: 937-951. 
Marshall AR, Blankenship HL, Connor WP (2000). Genetic characterization of naturally spawned Snake River fall-run chinook salmon. Trans Am Fish Soc 129: 680-698.

Myers JM, Kope RG, Bryant GJ, Teel D, Lierheimer LJ, Wainwright TC et al (1998). Status review of chinook salmon from Washington, Idaho, Oregon, and California NOAA Tech. Memo. NMFS-NWFSC-35. 443pp.

Morizot DC, Bednarz JC, Ferrell RE (1987). Sex linkage of muscle creatine kinase in Harris' hawks. Cytogenet Cell Genet 44: 89-91.

Muller HJ (1914). A gene for the fourth chromosome of Drosophila. J Exp Zool 17: 324-336.

Nagler JJ, Bouma J, Thorgaard GH, Dauble DD (2001). High incidence of a male-specific genetic marker in phenotypic female chinook salmon from the Columbia River. Environ Health Perspect 109: 67-69.

Nanda I, Kondo M, Hornung U, Asakawa S, Winkler C, Shimizu A et al (2002). A duplicated copy of DMRT1 in the sex-determining region of the Y chromosome of the medaka, Oryzias latipes. Proc Natl Acad Sci USA 99: 11778-11783.

Phillips R, Ráb P (2001). Chromosome evolution in the Salmonidae (Pisces): an update. Biol Rev 76: 1-25.

Rice WR (1996). Evolution of the Y sex chromosome in animals. BioScience 46: 331-343.

Sakamoto T, Danzmann RG, Gharbi K, Howard P, Okaki A, Khoo SK et al (2000). A microsatellite linkage map of rainbow trout (Oncorhynchus mykiss) characterized by large sexspecific differences in recombination rates. Genetics 155: 1331-1345.

Scheerer PD, Thorgaard GH, Allendorf FW (1991). Genetic analysis of androgenetic rainbow trout. J Exp Zool 260: 382-390.

Shaklee JB, Allendorf FW, Morizot DC, Whitt GS (1990). Gene nomenclature for protein-coding loci in fish. Trans Am Fish Soc 119: 2-15.

Siegismund HR, Christensen B (1992). A sex-linked enzyme polymorphism in the marine isopod Jaera ischiosetosa. J Hered 83: 388-393.
Spruell P, Pilgrim KL, Greene BA, Habicht C, Knudsen KL, Lindner KR et al (1999). Inheritance of nuclear DNA markers in gynogenetic haploid pink salmon (Oncorhynchus gorbuscha). I Hered 90: 289-296.

Teel DJ, Crane PA, Guthrie CM, Marshall AR, VanDoornik DM, Templin WD et al (1999). Comprehensive allozyme database discriminates chinook salmon around the Pacific Rim. North Pacific Anadromous Fish Commission Document 440. Alaska Department of Fish and Game, Division of Commercial Fisheries, Anchorage, Alaska.

Thorson RM (1980). Ice-sheet glaciation of the Puget lowland, Washington, during the Vashon stade (late Pleistocene). Quaternary Res 13: 303-321.

Utter FM, Milner GB, Ståhl G, Teel DJ (1989). Genetic population structure of chinook salmon, Oncorhynchus tshawytscha, in the Pacific Northwest. Fish Bull 87: $13-23$.

Wang JL (1999). Effective size and F-statistics of subdivided populations for sex-linked loci. Theor Popul Biol 55: 176-188.

Winge O (1927). The location of eighteen genes in Lebistes reticulatus. J Genet 18: 1-43.

Woram RA, Gharbi K, Sakamoto T, Hoyheim B, Holm L-E, Naish K et al (2003). Comparative genome analysis of the primary sex-determining locus in salmonid fishes. Genome Res 13: 272-280.

Wright DA, Richards CM (1983). Two sex-linked loci in the leopard frog, Rana pipiens. Genetics 103: 249-261.

Zhang Q, Nakayama I, Fujiwara A, Kobayashi T, Oohara I, Masoka $\mathrm{T}$ et al (2001). Sex identification by male-specific growth hormone pseudogene (GH- $\Psi$ ) in Oncorhynchus masou complex and related hybrid. Genetica 111: 111-118.

\section{Appendix}

Distribution of genotypes at PEPB-1 and probabilities on the allele frequencies are given in the Table A1.

Table A1 Distribution of genotypes at PEPB-1 in chinook salmon. $F$ is the fixation index (relative excess or deficit of heterozygotes). The estimated haplotype frequencies are given in the female (F; $X^{-*} a, X-{ }^{*} b$, and $\left.X^{-}{ }^{*} c\right)$ and male $\left(\mathrm{M} ; Y^{-}{ }^{*} a, Y^{*} b\right.$, and $\left.Y^{-}{ }^{*} c\right)$ rows for each sample. The probabilities on the allele frequencies in the total sample are for contingency tests for allele frequency differences between females and males

\begin{tabular}{|c|c|c|c|c|c|c|c|c|c|c|}
\hline \multirow[t]{2}{*}{ Sample } & \multicolumn{6}{|c|}{ Genotypes } & \multirow[b]{2}{*}{$F$} & \multicolumn{3}{|c|}{ Allele frequency } \\
\hline & $a a$ & $a b$ & $b b$ & $a c$ & $b c$ & $c c$ & & $a$ & $b$ & $c$ \\
\hline \multicolumn{11}{|c|}{ A1 Harrison River } \\
\hline $\mathrm{F}$ & 52 & 6 & 2 & 1 & 0 & 0 & 0.31 & 0.907 & 0.087 & 0.006 \\
\hline \multirow[t]{2}{*}{ M } & 0 & 35 & 4 & 0 & 0 & 0 & $-0.81^{* * *}$ & 0 & 1.000 & 0 \\
\hline & 52 & 41 & 6 & 1 & 0 & 0 & -0.06 & $0.730^{* * *}$ & $0.265^{* * *}$ & 0.005 \\
\hline \multicolumn{11}{|c|}{ A2 Chehalis Hatchery } \\
\hline $\mathrm{F}$ & 197 & 46 & 3 & 4 & 1 & 0 & 0.02 & 0.886 & 0.106 & 0.008 \\
\hline \multirow[t]{2}{*}{$\mathrm{M}$} & 7 & 202 & 24 & 0 & 1 & 0 & $-0.74^{* * *}$ & 0.033 & 0.967 & 0 \\
\hline & 204 & 248 & 27 & 4 & 2 & 0 & $-0.19^{* * *}$ & $0.680^{* * *}$ & $0.313^{* * *}$ & 0.006 \\
\hline \multicolumn{11}{|c|}{ A3 Tenderfoot Hatchery } \\
\hline $\mathrm{F}$ & 44 & 50 & 13 & 1 & 0 & 0 & -0.02 & 0.646 & 0.350 & 0.004 \\
\hline \multirow[t]{2}{*}{ M } & 20 & 47 & 20 & 2 & 0 & 0 & -0.08 & 0.349 & 0.631 & 0.020 \\
\hline & 64 & 97 & 33 & 3 & 0 & 0 & -0.03 & $0.579^{* *}$ & $0.414^{* *}$ & 0.008 \\
\hline \multicolumn{11}{|c|}{ B1 Cowichan River } \\
\hline $\mathrm{F}$ & 86 & 176 & 112 & 0 & 0 & 0 & 0.05 & 0.465 & 0.535 & 0 \\
\hline \multirow[t]{2}{*}{$\mathrm{M}$} & 95 & 163 & 63 & 0 & 0 & 0 & -0.03 & 0.634 & 0.366 & 0 \\
\hline & 181 & 339 & 175 & 0 & 0 & 0 & 0.02 & $0.504^{* *}$ & $0.496^{* *}$ & 0 \\
\hline
\end{tabular}


Table A1 (Continued)

Sample

Genotypes

$a c \quad b c \quad c c$

B2 Conuma River

F

31
37

18

13

68

31

C1 North Fork Nooksack

$\begin{array}{lrr}\mathrm{F} & 74 & 14 \\ \mathrm{M} & 1 & 79 \\ & 75 & 93\end{array}$

C2 South Fork Nooksack

$\begin{array}{lrr}\mathrm{F} & 37 & 16 \\ \mathrm{M} & 7 & 18 \\ & & \\ & 44 & 34\end{array}$

C3 Suiattle River

$\mathrm{F} \quad 137$

$137 \quad 31$

$145 \quad 138$

C4 Cascade River

$\mathrm{F}$

32
2

34

C5 Skagit Hatchery

$\mathrm{F}$

95

C6 Skagit River

$\begin{array}{lrr}\text { F } & 57 & 2 \\ \mathrm{M} & 2 & 70 \\ & 59 & 9\end{array}$

C7 Skykomish River

$\begin{array}{lrr}\text { F } & 52 & 17 \\ \mathrm{M} & 2 & 25 \\ & & \\ & 54 & 42\end{array}$

C8 Sultan River

$\mathrm{F}$

$\begin{array}{rr}30 & 24 \\ 3 & 27\end{array}$

33

51

C9 Snoqualmie River$$
\mathrm{F}
$$

$\begin{array}{ll}35 & 12 \\ 10 & 30\end{array}$

45

42

C10 Cedar River

$\begin{array}{lrr}\mathrm{F} & 38 & 2 \\ \mathrm{M} & 0 & 2 \\ & 38 & 5\end{array}$

C11 Green River Hatchery

$\begin{array}{lrr}\mathrm{F} & 80 & 50 \\ \mathrm{M} & 1 & 119 \\ & & \\ & 81 & 169\end{array}$

16
18

1
0
1

0

0
0
0

$\begin{array}{rrr}0 & 20 & 1 \\ 6 & 1 & 4 \\ 6 & 21 & 5\end{array}$

$\begin{array}{ll}1 & 2 \\ 4 & 0 \\ 5 & 2\end{array}$

0
0
0

$\begin{array}{rll}5 & 0 & 0 \\ 14 & 0 & 0 \\ 19 & 0 & 0\end{array}$

0
0
0

$\begin{array}{ll}1 & 0 \\ 7 & 0 \\ 8 & 0\end{array}$

0
0
0

-0.12
-0.15
-0.13

1
0
1

-0.06
$-0.76^{* * *}$
$-0.21^{* *}$

$\begin{array}{ll}0 & -0.07 \\ 0 & -0.25 \\ 0 & -0.06\end{array}$

\begin{tabular}{|c|c|c|}
\hline-0.06 & $0.729^{* * *}$ & $0.259^{* * *}$ \\
\hline
\end{tabular}

$\begin{array}{llll}0.14 & 0.882 & 0.118 & 0 \\ -0.66^{* * *} & 0.070 & 0.930 & 0 \\ -0.11 & 0.709^{* * *} & 0.291^{* * *} & 0\end{array}$


Table A1 (Continued)

\begin{tabular}{|c|c|c|c|c|c|c|c|c|c|c|}
\hline \multirow[t]{2}{*}{ Sample } & \multicolumn{6}{|c|}{ Genotypes } & \multirow[b]{2}{*}{$F$} & \multicolumn{3}{|c|}{ Allele frequency } \\
\hline & $a a$ & $a b$ & $b b$ & $a c$ & $b c$ & $c c$ & & $a$ & $b$ & $c$ \\
\hline \multicolumn{11}{|c|}{ C12 Newaukum River } \\
\hline $\mathrm{F}$ & 42 & 21 & 4 & 0 & 0 & 0 & 0.08 & 0.801 & 0.199 & 0 \\
\hline \multirow[t]{2}{*}{$\mathrm{M}$} & 0 & 64 & 13 & 0 & 0 & 0 & $-0.71^{* * *}$ & 0 & 1.000 & 0 \\
\hline & 42 & 85 & 17 & 0 & 0 & 0 & $-0.22^{*}$ & $0.587^{* * *}$ & $0.413^{* * *}$ & 0 \\
\hline \multicolumn{11}{|c|}{ C13 White River Hatchery } \\
\hline $\mathrm{F}$ & 188 & 179 & 24 & 0 & 0 & 0 & $-0.11^{*}$ & 0.734 & 0.266 & 0 \\
\hline \multirow[t]{2}{*}{$\mathrm{M}$} & 1 & 242 & 62 & 0 & 0 & 0 & $-0.65^{* * *}$ & 0.005 & 0.995 & 0 \\
\hline & 189 & 421 & 86 & 0 & 0 & 0 & $-0.24^{* * *}$ & $0.574^{* * *}$ & $0.426^{* * *}$ & 0 \\
\hline \multicolumn{11}{|c|}{ C14 Puyallup Hatchery } \\
\hline $\mathrm{F}$ & 34 & 33 & 9 & 0 & 0 & 0 & 0.03 & 0.679 & 0.321 & 0 \\
\hline \multirow[t]{2}{*}{ M } & 1 & 52 & 21 & 0 & 0 & 0 & $-0.52^{* * *}$ & 0.020 & 0.980 & 0 \\
\hline & 35 & 85 & 30 & 0 & 0 & 0 & -0.13 & $0.517^{* * *}$ & $0.483^{* * *}$ & 0 \\
\hline \multicolumn{11}{|c|}{ C15 South Prarie Creek } \\
\hline $\mathrm{F}$ & 28 & 21 & 5 & 0 & 0 & 0 & 0.05 & 0.711 & 0.289 & 0 \\
\hline \multirow[t]{2}{*}{$\mathrm{M}$} & 1 & 22 & 9 & 0 & 0 & 0 & $-0.47^{*}$ & 0.044 & 0.956 & 0 \\
\hline & 29 & 43 & 14 & 0 & 0 & 0 & -0.03 & $0.587^{* * *}$ & $0.413^{* * *}$ & 0 \\
\hline \multicolumn{11}{|c|}{ C16 Hood Canal Hatchery } \\
\hline $\mathrm{F}$ & 43 & 25 & 7 & 0 & 0 & 0 & 0.13 & 0.729 & 0.271 & 0 \\
\hline \multirow[t]{2}{*}{$\mathrm{M}$} & 0 & 53 & 22 & 0 & 0 & 0 & $-0.55^{* * *}$ & 0 & 1.000 & 0 \\
\hline & 43 & 78 & 29 & 0 & 0 & 0 & -0.05 & $0.547^{* * *}$ & $0.453^{* * *}$ & 0 \\
\hline \multicolumn{11}{|c|}{ D1 Elwha River } \\
\hline $\mathrm{F}$ & 71 & 15 & 2 & 4 & 2 & 0 & 0.12 & 0.842 & 0.124 & 0.034 \\
\hline \multirow[t]{2}{*}{$\mathrm{M}$} & 11 & 77 & 14 & 0 & 4 & 0 & $-0.48^{* * *}$ & 0.118 & 0.882 & 0 \\
\hline & 82 & 92 & 16 & 4 & 6 & 0 & -0.08 & $0.650^{* * *}$ & $0.325^{* * *}$ & 0.025 \\
\hline
\end{tabular}

D2 Hoko River$$
\text { F }
$$

F

$\begin{array}{ll}28 & 13 \\ 19 & 18 \\ & \\ 47 & 31\end{array}$

1 
Table A1 (Continued)

\begin{tabular}{|c|c|c|c|c|c|c|c|c|c|c|}
\hline \multirow[t]{2}{*}{ Sample } & \multicolumn{6}{|c|}{ Genotypes } & \multirow[b]{2}{*}{$F$} & \multicolumn{3}{|c|}{ Allele frequency } \\
\hline & $a a$ & $a b$ & $b b$ & $a c$ & $b c$ & $c c$ & & $a$ & $b$ & $c$ \\
\hline \multicolumn{11}{|c|}{ E1 Cowlitz Hatchery } \\
\hline $\mathrm{F}$ & 39 & 3 & 1 & 6 & 1 & 0 & 0.15 & 0.889 & 0.064 & 0.047 \\
\hline \multirow[t]{2}{*}{$\mathrm{M}$} & 37 & 11 & 1 & 0 & 0 & 0 & 0.02 & 0.807 & 0.193 & 0 \\
\hline & 76 & 14 & 2 & 6 & 1 & 0 & 0.10 & 0.869 & 0.096 & $0.035^{*}$ \\
\hline \multicolumn{11}{|c|}{ E2 Kalama Hatchery-A } \\
\hline $\mathrm{F}$ & 40 & 6 & 0 & 6 & 0 & 0 & -0.09 & 0.878 & 0.061 & 0.061 \\
\hline \multirow[t]{2}{*}{$\mathrm{M}$} & 45 & 5 & 0 & 4 & 0 & 0 & -0.07 & 0.968 & 0.025 & 0.007 \\
\hline & 85 & 11 & 0 & 10 & 0 & 0 & -0.08 & 0.901 & 0.052 & 0.047 \\
\hline \multicolumn{11}{|c|}{ E3 Kalama Hatchery-B } \\
\hline F & 53 & 17 & 2 & 3 & 0 & 0 & 0.03 & 0.844 & 0.138 & 0.018 \\
\hline \multirow[t]{2}{*}{$\mathrm{M}$} & 45 & 26 & 2 & 1 & 0 & 0 & -0.09 & 0.729 & 0.271 & 0 \\
\hline & 98 & 43 & 4 & 4 & 0 & 0 & -0.03 & 0.815 & 0.171 & 0.013 \\
\hline \multicolumn{11}{|c|}{ E4 Lewis Hatchery-A } \\
\hline $\mathrm{F}$ & 35 & 8 & 0 & 4 & 1 & 0 & -0.05 & 0.852 & 0.109 & 0.039 \\
\hline \multirow[t]{2}{*}{$\mathrm{M}$} & 72 & 8 & 0 & 3 & 3 & 1 & 0.20 & 0.933 & 0 & 0.067 \\
\hline & 107 & 16 & 0 & 7 & 4 & 1 & 0.10 & 0.878 & 0.074 & 0.048 \\
\hline \multicolumn{11}{|c|}{ E5 Lewis Hatchery-B } \\
\hline $\mathrm{F}$ & 73 & 6 & 0 & 5 & 0 & 0 & -0.05 & 0.935 & 0.036 & 0.030 \\
\hline \multirow[t]{2}{*}{$\mathrm{M}$} & 31 & 3 & 0 & 2 & 0 & 0 & -0.06 & 0.926 & 0.048 & 0.026 \\
\hline & 104 & 9 & 0 & 7 & 0 & 0 & -0.05 & 0.933 & 0.038 & 0.029 \\
\hline \multicolumn{11}{|c|}{ E6 Clackamas Hatchery } \\
\hline $\mathrm{F}$ & 54 & 4 & 0 & 0 & 0 & 0 & -0.04 & 0.967 & 0.033 & 0 \\
\hline \multirow[t]{2}{*}{$\mathrm{M}$} & 36 & 6 & 0 & 0 & 0 & 0 & -0.08 & 0.888 & 0.112 & 0 \\
\hline & 90 & 10 & 0 & 0 & 0 & 0 & -0.05 & 0.950 & 0.050 & 0 \\
\hline \multicolumn{11}{|c|}{ E7 Marion Forks Hatchery } \\
\hline $\mathrm{F}$ & 43 & 5 & 0 & 0 & 0 & 0 & -0.05 & 0.946 & 0.054 & 0 \\
\hline \multirow[t]{2}{*}{ M } & 49 & 3 & 0 & 0 & 0 & 0 & -0.03 & 0.999 & 0.001 & 0 \\
\hline & 92 & 8 & 0 & 0 & 0 & 0 & -0.04 & 0.960 & 0.040 & 0 \\
\hline \multicolumn{11}{|c|}{ E8 McKenzie Hatchery } \\
\hline $\mathrm{F}$ & 45 & 10 & 0 & 0 & 0 & 0 & -0.10 & 0.905 & 0.095 & 0 \\
\hline M & 36 & 17 & 2 & 0 & 0 & 0 & 0.00 & 0.720 & 0.280 & 0 \\
\hline & 81 & 27 & 2 & 0 & 0 & 0 & -0.01 & $0.859^{*}$ & $0.141^{*}$ & 0 \\
\hline E9 Spri & ek Ha & & & & & & & & & \\
\hline $\mathrm{F}$ & 59 & 21 & 1 & 0 & 0 & 0 & -0.06 & 0.862 & 0.138 & 0 \\
\hline M & 45 & 23 & 1 & 0 & 0 & 0 & -0.12 & 0.768 & 0.232 & 0 \\
\hline & 104 & 44 & 2 & 0 & 0 & 0 & -0.09 & 0.840 & 0.160 & 0 \\
\hline E10 Kli & Hatch & & & & & & & & & \\
\hline $\mathrm{F}$ & 173 & 14 & 0 & 20 & 0 & 0 & -0.07 & 0.919 & 0.034 & 0.047 \\
\hline M & 170 & 14 & 0 & 12 & 0 & 1 & 0.02 & 0.937 & 0.036 & 0.027 \\
\hline & 343 & 28 & 0 & 32 & 0 & 1 & -0.03 & 0.923 & 0.035 & 0.042 \\
\hline E11 Kli & River & & & & & & & & & \\
\hline $\mathrm{F}$ & 141 & 21 & 1 & 13 & 2 & 0 & 0.02 & 0.888 & 0.070 & 0.042 \\
\hline $\mathrm{M}$ & 61 & 11 & 1 & 7 & 0 & 0 & 0.00 & 0.862 & 0.091 & 0.047 \\
\hline & 202 & 32 & 2 & 20 & 2 & 0 & 0.01 & 0.884 & 0.074 & 0.043 \\
\hline F1 Mari & & & & & & & & & & \\
\hline $\mathrm{F}$ & 105 & 14 & 2 & 8 & 0 & 0 & 0.08 & 0.897 & 0.072 & 0.031 \\
\hline M & 188 & 36 & 2 & 7 & 0 & 0 & 0.00 & 0.903 & 0.097 & 0 \\
\hline & 293 & 50 & 4 & 15 & 0 & 0 & 0.03 & 0.899 & 0.080 & 0.021 \\
\hline
\end{tabular}


Table A1 (Continued)

Sample

\begin{tabular}{llllll}
\multicolumn{9}{c}{ Genotypes } \\
\hline$a a$ & $a b$ & $b b$ & $a c$ & $b c$ & $c c$
\end{tabular}

F2 Lyons Ferry Hatchery

$\mathrm{F}$
$\mathrm{M}$

$\begin{array}{ll}201 & 51 \\ 171 & 48\end{array}$

372

F3 Hanford Reach

$\begin{array}{ll}\mathrm{F} & 36 \\ \mathrm{M} & 17\end{array}$

$\begin{array}{ll}36 & 21 \\ 17 & 10 \\ 53 & 31\end{array}$

$53 \quad 31$

F4 Priest Rapids Hatchery

$\mathrm{F}$

$\mathrm{F}$

$\begin{array}{ll}63 & 30 \\ 49 & 37\end{array}$

112

F5 Wenatchee River$$
\text { F }
$$

$\mathrm{M}$

$\begin{array}{lrr}175 & 110 & 28 \\ 151 & 84 & 22 \\ 326 & 194 & 50\end{array}$

F6 Similkameen River

$\begin{array}{llll}\mathrm{F} & 24 & 22 & 12 \\ \mathrm{M} & 30 & 29 & \\ & 54 & 51 & 18\end{array}$

G1 Round Butte Hatchery$$
\text { F }
$$

$\begin{array}{ll}45 & 4 \\ 33 & 3 \\ 78 & 7\end{array}$

G2 Naches River

$$
\begin{array}{ll}
\mathrm{F} & 148 \\
\mathrm{M} & 131
\end{array}
$$$$
\begin{aligned}
& 148 \\
& 131
\end{aligned}
$$$$
279
$$

38
279

G3 American River$$
\text { F }
$$

255
194
449

G4 Upper Yakima River

$\begin{array}{lrr}\mathrm{F} & 136 & 35 \\ \mathrm{M} & 82 & 18 \\ & 218 & 53\end{array}$

G5 Cle Elum River$$
\text { F }
$$

$\mathrm{F}$

$\begin{array}{rr}46 & 12 \\ 25 & 4\end{array}$

G6 Tucannon River

$$
\mathrm{F}
$$

\begin{tabular}{rr}
87 & 7 \\
97 & 7 \\
& \\
\hline
\end{tabular}

G7 Chiwawa River

$$
\text { F }
$$

$\begin{array}{ll}2 & 0 \\ 0 & 0 \\ 2 & 0\end{array}$

$$
\begin{aligned}
& 98 \\
& 66
\end{aligned}
$$

164

0

F

99

67

30
37

13

13

$$
28
$$$$
50
$$

\begin{tabular}{l}
6 \\
7 \\
\hline
\end{tabular}

4
0
4

\subsection{3}

0.02

0.08
$-0.02$
0.16

0.05

0.09

0.00

0.05

0.09

0.11

0.10

0.20

$-0.03$

0.09

$-0.07$

0.18

0.09

$\begin{array}{ll}0 & 12\end{array}$

22
9

31

6
2
8

6
2

8

35

53

$$
\begin{array}{r}
12 \\
4
\end{array}
$$

16

$$
\begin{aligned}
& 7 \\
& 7
\end{aligned}
$$$$
14
$$

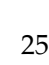

25
13

38

0

20
27
47

\subsection{0}

0.04

0.02

$-0.01$

$-0.04$

$-0.02$

0.01

$-0.02$

0.00

$-0.07$

0.18

0.01

-0.04
-0.09
-0.06

$-0.06$

0.05

0.10

0.07

3

30

4

4

0.861
0.881
0.865

0.130

0.119

0.128

0.760

0.669
0.669

0.222

0.326

0.239

0.005

0.745

0.215

0.327

0.241

0.009

0

0.007

0.762
0.673

0.741

0.732

0.755

0.261

0.233

0.255

0.012

0.737

0.008

0.603
0.764

0.391

0.236

0.005

0.645

0.351

0

0.004

0.908
0.801

0.035

0.036

0.056

0.884

0.035

0.164

0.081

0.886
0.845

\subsection{4}

0.064
0.032

0.876

0.056

0.050
0.123

0.067

0.985

0.937

0.011

0.004

$0.975^{*}$

0.009

0.063

$0.017^{* * *}$

0.791

0.754

0.097

0.097
0.065

0.112

0.784

0.090

0.181

0.126

0.762

0.818

0.093

0.033

0.145

0.771

0.083

0.150

0.146

0.893

0.910

0.037

0.020

0.070

0.898

0.033

0.070

0.070 
Table A1 (Continued)

\begin{tabular}{|c|c|c|c|c|c|c|c|c|c|c|}
\hline \multirow[t]{2}{*}{ Sample } & \multicolumn{6}{|c|}{ Genotypes } & \multirow[b]{2}{*}{$F$} & \multicolumn{3}{|c|}{ Allele frequency } \\
\hline & $a a$ & $a b$ & $b b$ & $a c$ & $b c$ & $c c$ & & $a$ & $b$ & $c$ \\
\hline \multicolumn{11}{|c|}{ G8 White River } \\
\hline $\mathrm{F}$ & 44 & 9 & 0 & 13 & 0 & 1 & -0.06 & 0.825 & 0.064 & 0.111 \\
\hline \multirow[t]{2}{*}{ M } & 38 & 12 & 0 & 16 & 2 & 1 & -0.08 & 0.674 & 0.144 & 0.181 \\
\hline & 82 & 21 & 0 & 29 & 2 & 2 & -0.07 & 0.787 & 0.085 & 0.129 \\
\hline \multicolumn{11}{|c|}{ G9 Twisp River } \\
\hline $\mathrm{F}$ & 38 & 0 & 0 & 10 & 1 & 1 & 0.10 & 0.846 & 0.017 & 0.137 \\
\hline \multirow[t]{2}{*}{ M } & 17 & 3 & 0 & 28 & 3 & 4 & -0.18 & 0.362 & 0.079 & 0.559 \\
\hline & 55 & 3 & 0 & 38 & 4 & 5 & -0.02 & $0.719^{* * *}$ & 0.033 & $0.248^{* * *}$ \\
\hline \multicolumn{11}{|c|}{ G10 Chewack River } \\
\hline $\mathrm{F}$ & 44 & 13 & 1 & 18 & 3 & 4 & 0.08 & 0.724 & 0.106 & 0.169 \\
\hline \multirow[t]{2}{*}{ M } & 43 & 8 & 1 & 11 & 2 & 3 & 0.18 & 0.802 & 0.075 & 0.123 \\
\hline & 87 & 21 & 2 & 29 & 5 & 7 & 0.12 & 0.742 & 0.099 & 0.159 \\
\hline
\end{tabular}

${ }^{*} P<0.05 ;{ }^{* * P}<0.01 ;{ }^{* * *} P<0.001$. 